\title{
Preparation of Superconducting Lead-Alloy Long Filaments by Glass-Coated Melt Spinning
}

\author{
By Tomoko Gotō*
}

\begin{abstract}
The glass-coated melt spinning of $\mathrm{Pb}$ alloy was investigated to produce a superconducting long filament with $T_{c}$ more than $4.2 \mathrm{~K}$.

Continuous smooth filaments less than $60 \mu \mathrm{m}$ in diameter of $\mathrm{Pb}$, and $\mathrm{Pb}-\mathrm{Bi}, \mathrm{Pb}-\mathrm{In}$ and $\mathrm{Pb}-\mathrm{Sn}$ system alloys, and of $\mathrm{Pb}_{84.4} \mathrm{Au}_{15.6}$ and $\mathrm{In}_{2} \mathrm{Bi}$ alloys were obtained from a molten state at $1450 \mathrm{~K}$ with various spinning speeds ranging from $0.95 \mathrm{~m} / \mathrm{s}$ to $7.95 \mathrm{~m} / \mathrm{s}$. The $\mathrm{Pb}$ system alloy filament obtained was a ductile material with the tensile strength of $40 \mathrm{MPa}$ and elongation of $2.0 \%$.

The $T_{c}$ of the $\mathrm{Pb}$ alloy filament did not depend on the sample current density $\left(J_{s}\right)$ less than $3 \times$ $10^{7} \mathrm{~A} / \mathrm{m}^{2}$, whereas the $T_{c}$ of the $\mathrm{Pb}$ filament depended on the $J_{s}$ more than $2 \times 10^{6} \mathrm{~A} / \mathrm{m}^{2}$. The maximum $T_{c}$ at $8.0 \mathrm{~K}$ was observed for the $\mathrm{Pb}_{60.2} \mathrm{Bi}_{39.8}$ filament.

The enhancement of superconductivity was observed for the $\mathrm{Pb}_{70} \mathrm{Sn}_{30}$ and $\mathrm{Pb}_{65} \mathrm{Sn}_{35}$ filaments.
\end{abstract}

(Received March 24, 1983)

Keywords: superconducting long filament, glass-coated melt spinning, lead alloy

\section{Introduction}

The formation of superconducting filaments has been attempted directly from molten metal by the glass-coated melt spinning process ${ }^{(1)-(3)}$. In a previous paper, a $\mathrm{Cu}-\mathrm{V}-\mathrm{Si}$ superconducting long filament with $T_{c}$ of $11 \mathrm{~K}$ was produced by using this method. It is well known that $T_{c}$ of the material exhibiting superconductivity due to the proximity effect, varies drastically with current density. The $\mathrm{Cu}-\mathrm{V}-\mathrm{Si}$ filament obtained was so fine as to be $10 \mu \mathrm{m}$ in diameter, resulting in a very high sample current density $\left(J_{s}\right)$ of the filament ranging from $10^{6}$ to $10^{8} \mathrm{~A} /$ $\mathrm{m}^{2}$. Therefore, a high $T_{c}$ such as $17 \mathrm{~K}$ for $\mathrm{V}_{3} \mathrm{Si}$ was not observed ${ }^{(3)}$. This paper describes the melt spinning of lead alloys for producing a superconducting long filament with $T_{c}$ more than $4.2 \mathrm{~K}$.

\section{Experimental}

The melt spinning of $\mathrm{Pb}$, and $\mathrm{Pb}-\mathrm{Bi}, \mathrm{Pb}-\mathrm{In}$ and $\mathrm{Pb}-\mathrm{Sn}$ system alloys, and of $\mathrm{Pb}_{84.4} \mathrm{Au}_{15.6}$ and $\mathrm{In}_{2} \mathrm{Bi}$ alloys was carried out by using the same method as that used for $\mathrm{Cu}-\mathrm{V}-\mathrm{Si}$ alloys ${ }^{(3)}$.

* Nagoya Institute of Technology, Department of Polymer Technology, Gokiso-chō Shōwa-ku, Nagoya 466 , Japan.
Mother alloys of $\mathrm{Pb}-\mathrm{Bi}, \mathrm{Pb}-\mathrm{Sn}$ and $\mathrm{Pb}-\mathrm{Au}$ were produced by melting $\mathrm{Pb}$ and other metals in a vacuum. About $1 \mathrm{~g}$ of the alloy was placed in a pyrex glass tube and melted by induction heating in an argon atmosphere. As the clean mother alloy could not be obtained for the In alloy, a mixture of In and other metals of appropriate composition was placed in a pyrex glass tube and melted by induction heating in an argon atmosphere.

When the glass tube containing the molten alloy was drawn, the alloy was stretched to form a glass-coated metallic filament and coiled on a winding drum. The coating glass was removed in a $45 \% \mathrm{HF}$ aqueous solution.

The tensile strength of the filament produced by this method was measured with an Instron type machine, and the crystal structure of the filament was examined by an X-ray diffractometer. The $T_{c}$ of the filament was measured by the resistive method.

\section{Results and Discussion}

\section{1. $\mathbf{P b}$ and $\mathbf{P b}-\mathbf{B i}$ alloy filaments}

Continuous $\mathrm{Pb}$ filaments were produced from a molten state at a temperature of about $1450 \mathrm{~K}$ with various spinning speeds ranging from $0.95 \mathrm{~m} / \mathrm{s}$ to $7.95 \mathrm{~m} / \mathrm{s}$. The effect of the spinning speed on the tensile strength and diameter of 
the filament is shown in Table 1. The diameter decreases slightly with increasing spinning speed. Although the usual $\mathrm{Pb}$ metal has the tensile strength of $18 \mathrm{MPa}$ with the elongation of $40 \%$, the $\mathrm{Pb}$ filament spun at the spinning speed of $7.95 \mathrm{~m} / \mathrm{s}$ has the high tensile strength of $40 \mathrm{MPa}$ with the low elongation of $1.5 \%$. Plasticity of these filaments was observed on the stress-strain curve and the fracture morphology. The filament obtained had a lustrous smooth surface and was free from pinholes. Crosssections of the filament after chemical etching were observed by scanning electron microscopy. The filament consisted of fine crystal grains with grain size of $1500 \times 10^{-10} \mathrm{~m}$.

$T_{c}$ of the filament was determined by measuring changes in resistivity of a specimen $20 \mathrm{~mm}$ in length as a function of temperature using a chromel-gold $+0.007 \%$ iron thermocouple. The filament was found to be superconducting with the reasonable sharp transition. $T_{c}$ was chosen as the temperature at which the filament resistance reached a half of its normal value. The transition width was of the order of magnitude less than $0.2 \mathrm{~K}$. The remarkable dependence of the $T_{c}$ on the $J_{s}$ is observed as shown in Fig. 1. The reasonable $T_{c}$ of $7.2 \mathrm{~K}$ for $\mathrm{Pb}$ element is measured at $J_{s}$ less than $2 \times$ $10^{6} \mathrm{~A} / \mathrm{m}^{2(4)}$.

$\mathrm{Pb}_{x} \mathrm{Bi}_{100-x}(x=85,75,60.2,55,43.5,38)$ filaments were produced by the same method as for the $\mathrm{Pb}$ filament. The filament obtained had a lustrous smooth surface and was found to be polycrystalline with a grain size of $1000 \times$ $10^{-10} \mathrm{~m}$. The average diameter, tensile strength and crystal structure of the filament spun at various spinning speeds are listed in Table 2. The diameter of the filament decreases with increasing spinning speed. The effect of the wind-

Table 1 Spinning conditions and average strength of the $\mathrm{Pb}$ filaments produced by the melt spinning with pyrex glass.

\begin{tabular}{cccc}
\hline $\begin{array}{c}\text { Winding } \\
\text { speed } \\
(\mathrm{m} / \mathrm{s})\end{array}$ & $\begin{array}{c}\text { Diameter } \\
(\mu \mathrm{m})\end{array}$ & $\begin{array}{c}\text { Tensile } \\
\text { strength } \\
(\mathrm{MPa})\end{array}$ & $\begin{array}{c}\text { Elongation } \\
(\%)\end{array}$ \\
\hline 0.95 & 26 & 20 & 5.4 \\
2.63 & 25 & 10 & 2.0 \\
3.97 & 26 & 30 & 9.0 \\
7.95 & 13 & 40 & 1.5 \\
\hline
\end{tabular}

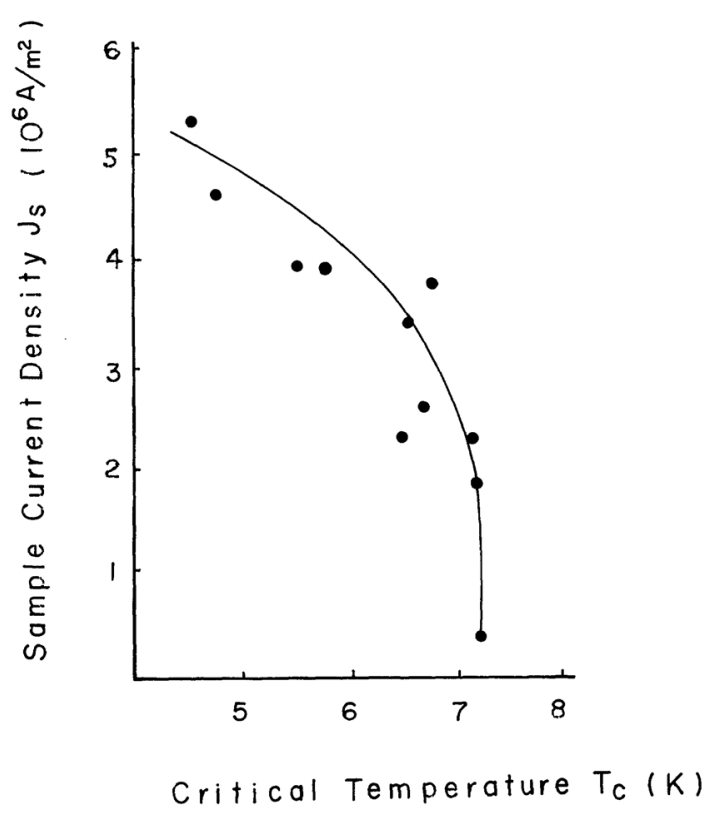

Fig. 1 Relation between the critical transition temperature $\left(T_{c}\right)$ and sample current density $\left(J_{s}\right)$ for the $\mathrm{Pb}$ filament.

ing speed on the tensile strength and crystal structure of the filament was not remarkable. The crystal structure of the filament agrees with that in the normal phase diagram ${ }^{(4)}$.

$T_{c}$ of the filament obtained was measured by the same method as for the $\mathrm{Pb}$ filament. Several $T_{c}$ 's for the $\mathrm{Pb}_{60.2} \mathrm{Bi}_{39.8}$ filaments spun at various spinning speeds are shown in Table 3. The $T_{c}$ is independent of the $J_{s}$ less than $4 \times$ $10^{7} \mathrm{~A} / \mathrm{m}^{2}$ and increases with decreasing spinning speed. The observed maximum $T_{c}$ of the filaments of various compositions of $\mathrm{Pb}-\mathrm{Bi}$ alloys, spun at the low spinning speed of $0.95 \mathrm{~m} / \mathrm{s}$ is shown in Table 4. A high $T_{c}$ of $8.0 \mathrm{~K}$ was observed for the $\mathrm{Pb}_{60.2} \mathrm{Bi}_{39.8}$ filament. J. G. Adler and S. C. $\mathrm{Ng}$ measured the maximum $T_{c}$ at $8.67 \mathrm{~K}$ for a $\mathrm{Pb}_{60.2} \mathrm{Bi}_{39.8}$ alloy film ${ }^{(5)}$. It was also reported that the $\mathrm{Pb}_{60}$ $\mathrm{Bi}_{40}$ alloy impregnated by the porous glass exhibited the superconductivity at $T_{c}=8.5 \mathrm{~K}^{(6)}$. On the other hand, it was studied for amorphous $\mathrm{Pb}-\mathrm{Bi}$ alloy films produced by the quenched condensation that the maximum $T_{c}$ was measured at $7.1 \mathrm{~K}$ for the composition of $\mathrm{Pb}_{50} \mathrm{Bi}_{50}$ and during annealing new unknown phases with increased $T_{c}$ 's were found ${ }^{(7)}$. It was 
Table 2 Spinning conditions and average strength, and crystal structure of the $\mathrm{Pb}-\mathrm{Bi}$ alloy filaments produced by the melt spinning with pyrex glass.

\begin{tabular}{|c|c|c|c|c|c|}
\hline Alloys & $\begin{array}{l}\text { Winding speed } \\
(\mathrm{m} / \mathrm{s})\end{array}$ & $\begin{array}{l}\text { Diameter } \\
(\mu \mathrm{m})\end{array}$ & $\begin{array}{l}\text { Tensile strength } \\
(\mathrm{MPa})\end{array}$ & $\underset{(\%)}{\text { Elongation }}$ & Crystal structure \\
\hline \multirow[t]{2}{*}{$\mathrm{Pb}_{85} \mathrm{Bi}_{15}$} & 0.95 & 49 & 40 & 3.8 & \multirow[t]{2}{*}{$\mathrm{Pb}^{*}+\varepsilon^{* *}$} \\
\hline & 1.50 & 32 & 30 & 2.2 & \\
\hline \multirow[t]{2}{*}{$\mathrm{Pb}_{75} \mathrm{Bi}_{25}$} & 1.50 & 38 & 30 & 1.1 & \multirow[t]{2}{*}{$\mathrm{Pb}+\varepsilon$} \\
\hline & 7.95 & 28 & 10 & 1.2 & \\
\hline \multirow[t]{3}{*}{$\mathrm{Pb}_{60.2} \mathrm{Bi}_{39.8}$} & 0.95 & 20 & 30 & 2.3 & \multirow{3}{*}{$\mathrm{Pb}+\varepsilon+\mathrm{Bi}^{* * *}$} \\
\hline & 1.50 & 20 & 20 & 2.0 & \\
\hline & 2.63 & 15 & 20 & 1.6 & \\
\hline \multirow[t]{3}{*}{$\mathrm{Pb}_{55} \mathrm{Bi}_{45}$} & 0.95 & 29 & 40 & 1.3 & \\
\hline & 2.63 & 30 & 40 & 2.0 & \multirow[t]{2}{*}{$\varepsilon+\mathrm{Bi}$} \\
\hline & 7.95 & 17 & 40 & 3.4 & \\
\hline \multirow[t]{2}{*}{$\mathrm{Pb}_{43.5} \mathrm{Bi}_{56.5}$} & 0.95 & 28 & 30 & 14.0 & \multirow[t]{2}{*}{$\varepsilon+\mathrm{Bi}$} \\
\hline & 7.95 & 18 & 40 & 2.6 & \\
\hline \multirow[t]{2}{*}{$\mathrm{Pb}_{38} \mathrm{Bi}_{62}$} & 0.95 & 67 & 40 & 1.6 & \multirow[t]{2}{*}{$\varepsilon+\mathrm{Bi}$} \\
\hline & 7.95 & 18 & 40 & 1.2 & \\
\hline
\end{tabular}

$\mathrm{Pb}^{*}: \quad f c c$ with $a=4.65 \times 10^{-10} \mathrm{~m}$.

$\varepsilon^{* *}: h c p$ with $a=3.50 \times 10^{-10} \mathrm{~m}, c=5.79 \times 10^{-10} \mathrm{~m}$.

$\mathrm{Bi}^{* * * *}: \quad h c p$ with $a=4.74 \times 10^{-10} \mathrm{~m}, c=11.9 \times 10^{-10} \mathrm{~m}$.

Table 3 Several $T_{c} \mathrm{~s}$ of the $\mathrm{Pb}_{60.2} \mathrm{Bi}_{39.8}$ filament spun at various winding speeds.

\begin{tabular}{cccc}
\hline $\begin{array}{c}\text { Winding } \\
\text { speeds }(\mathrm{m} / \mathrm{s})\end{array}$ & $\begin{array}{c}T_{\mathrm{c}} \\
(\mathrm{K})\end{array}$ & $\begin{array}{c}J_{\mathrm{s}} \\
\left(\times 10^{7} \mathrm{~A} / \mathrm{m}^{2}\right)\end{array}$ & $\begin{array}{c}\text { Diameter } \\
(\mu \mathrm{m})\end{array}$ \\
\hline 0.95 & 6.4 & 5.9 & 19 \\
0.95 & 8.0 & 4.2 & 24 \\
0.95 & 7.0 & 3.7 & 25 \\
1.50 & 6.4 & 19 & 11 \\
2.63 & 4.3 & 0.32 & 12 \\
2.63 & 5.1 & 0.58 & 9 \\
\hline \hline
\end{tabular}

Table 4 The maximum $T_{c}$ of the $\mathrm{Pb}-\mathrm{Bi}$ filament spun at a winding speed of $0.95 \mathrm{~m} / \mathrm{s}$.

\begin{tabular}{lcc}
\hline \hline Alloy filament & $T_{c}(\mathrm{~K})$ & $J_{s}\left(\times 10^{7} \mathrm{~A} / \mathrm{m}^{2}\right)$ \\
\hline $\mathrm{Pb}_{85} \mathrm{Bi}_{15}$ & 7.9 & 0.03 \\
$\mathrm{~Pb}_{75} \mathrm{Bi}_{25}$ & 6.5 & 0.10 \\
$\mathrm{~Pb}_{60.2} \mathrm{Bi}_{39.8}$ & 8.0 & 4.2 \\
$\mathrm{~Pb}_{55} \mathrm{Bi}_{45}$ & 7.9 & 0.28 \\
$\mathrm{~Pb}_{43.5} \mathrm{Bi}_{56.5}$ & 7.8 & 0.98 \\
$\mathrm{~Pb}_{38} \mathrm{Bi}_{62}$ & 7.3 & 1.2 \\
\hline \hline
\end{tabular}

found out that the $T_{c}$ of the $\mathrm{Pb}-\mathrm{Bi}$ alloy decreased by the rapid quenching ${ }^{(8)}$. The present filament was formed by the rapid quenching at a cooling rate higher than $10^{5} \mathrm{~K} / \mathrm{s}$ from the liquid state in the drawing process, and the rate was approximately proportional to the spinning speed ${ }^{(9)}$. Therefore, the $T_{c}$ of the $\mathrm{Pb}-\mathrm{Bi}$ filament increased by spinning at a low spin- ning speed and was slightly lower, compared with that for the bulk $\mathrm{Pb}-\mathrm{Bi}$ alloys.

\section{2. $\mathbf{P b}-\mathbf{I n}$ and $\mathbf{P b}-\mathrm{Sn}$ alloy filaments}

Continuous smooth filaments of $\mathrm{Pb}_{\boldsymbol{y}} \mathrm{In}_{100-y}$ $(y=70,50,30,25,15)$ and $\mathrm{Pb}_{z} \mathrm{Sn}_{100-z}(z=80$, $75,70,65,60)$ alloys were also successfully produced. The filaments obtained consisted of fine crystal grains with a grain size of $1000 \times$ $10^{-10} \mathrm{~m}$. Variations in the diameter, tensile strength and crystal structure of the filaments with various spinning speeds are listed in Table 5. The diameter of the $\mathrm{Pb}-\mathrm{Sn}$ filament obtained is finer than that of other alloy filaments. The dependences of the tensile strength on the spinning speed and on the additional element are not found out. The crystal structure of the $\mathrm{Pb}$-In filament is in agreement with that in the normal phase diagram. On the other hand, the structure of the $\mathrm{Pb}-\mathrm{Sn}$ filament is a single $f c c$ of $\mathrm{Pb}$ phase, and the extension of the solid solubility limit is observed.

Several $T_{c}$ 's of the $\mathrm{Pb}_{50} \mathrm{In}_{50}$ filaments spun at various winding speeds were measured and listed in Table 6. The remarkable dependences of the $T_{c}$ on the speed of spinning and on the $J_{s}$ less than $3 \times 10^{7} \mathrm{~A} / \mathrm{m}^{2}$ are not observed. The $T_{c}$ of the filaments of various compositions of $\mathrm{Pb}$-In alloys is shown in Fig. 2. The $\mathrm{Pb}_{15} \mathrm{In}_{85}$ 
Table 5 Spinning conditions and average diameter, and crystal structure of the $\mathrm{Pb}-\mathrm{In}$ and $\mathrm{Pb}-\mathrm{Sn}$ alloy filaments produced by the melt spinning with pyrex glass.

\begin{tabular}{|c|c|c|c|c|c|}
\hline Alloys & $\underset{(\mathrm{m} / \mathrm{s})}{\text { Winding speed }}$ & $\begin{array}{l}\text { Diameter } \\
(\mu \mathrm{m})\end{array}$ & $\begin{array}{l}\text { Tensile strength } \\
\text { (MPa) }\end{array}$ & $\begin{array}{c}\text { Elongation } \\
(\%)\end{array}$ & Crystal structure \\
\hline \multirow[t]{3}{*}{$\mathrm{Pb}_{70} \mathrm{In}_{30}$} & 0.95 & 68 & 30 & 14.0 & \\
\hline & 1.50 & 43 & 20 & 12.9 & $\mathrm{~Pb}$ \\
\hline & 2.63 & 21 & 20 & 4.8 & \\
\hline \multirow[t]{3}{*}{$\mathrm{Pb}_{50} \mathrm{In}_{50}$} & 0.95 & 66 & 20 & 2.2 & \\
\hline & 1.50 & 40 & 30 & 3.2 & $\mathrm{~Pb}$ \\
\hline & 2.63 & 30 & 30 & 3.7 & \\
\hline \multirow[t]{3}{*}{$\mathrm{Pb}_{30} \mathrm{In}_{70}$} & 0.95 & 78 & 30 & 2.3 & \\
\hline & 1.50 & 44 & 30 & 3.8 & InPb* \\
\hline & 2.63 & 38 & 40 & 1.7 & \\
\hline \multirow[t]{2}{*}{$\mathrm{Pb}_{25} \mathrm{In}_{75}$} & 0.95 & 73 & 20 & 6.3 & $\mathrm{InPb}^{*}$ \\
\hline & 1.50 & 54 & 10 & 3.7 & \\
\hline \multirow{2}{*}{$\mathrm{Pb}_{15} \mathrm{In}_{85}$} & 0.95 & 64 & 20 & 2.4 & InPb* \\
\hline & 1.50 & 35 & 20 & 2.4 & \\
\hline \multirow[t]{3}{*}{$\mathrm{Pb}_{80} \mathrm{Sn}_{20}$} & 0.95 & 26 & 30 & 2.0 & \\
\hline & 1.50 & 13 & 30 & 1.3 & $\mathrm{~Pb}$ \\
\hline & 2.63 & 13 & 30 & 0.9 & \\
\hline \multirow{2}{*}{$\mathrm{Pb}_{75} \mathrm{Sn}_{25}$} & 0.95 & 34 & 40 & 5.3 & \\
\hline & 1.50 & 23 & 30 & 3.1 & $\mathrm{~Pb}$ \\
\hline \multirow[t]{3}{*}{$\mathrm{Pb}_{70} \mathrm{Sn}_{30}$} & 0.95 & 22 & 40 & 2.1 & \\
\hline & 1.50 & 13 & 40 & 1.6 & $\mathrm{~Pb}$ \\
\hline & 2.63 & 8 & 30 & 1.8 & \\
\hline \multirow[t]{2}{*}{$\mathrm{Pb}_{65} \mathrm{Sn}_{35}$} & 0.95 & 22 & 50 & 1.5 & \\
\hline & 1.50 & 39 & 30 & 5.7 & $\mathbf{P b}$ \\
\hline $\mathrm{Pb}_{60} \mathrm{Sn}_{40}$ & 0.95 & 22 & 30 & 3.5 & $\mathrm{~Pb}$ \\
\hline
\end{tabular}

InPb*: $f c t$ with $a=4.90 \times 10^{-10} \mathrm{~m}, c=4.54 \times 10^{-10} \mathrm{~m}$.

Table 6 Several $T_{c} \mathrm{~s}$ of the $\mathrm{Pb}_{50} \mathrm{In}_{50}$ filament spun at various winding speeds.

\begin{tabular}{cccc}
\hline \hline $\begin{array}{c}\text { Winding } \\
\text { speed }(\mathrm{m} / \mathrm{s})\end{array}$ & $\begin{array}{c}T_{c} \\
(\mathrm{~K})\end{array}$ & $\begin{array}{c}J_{s} \\
\left(\times 10^{7} \mathrm{~A} / \mathrm{m}^{2}\right)\end{array}$ & $\begin{array}{c}\text { Diameter } \\
(\mu \mathrm{m})\end{array}$ \\
\hline 0.95 & 6.4 & 0.41 & 73 \\
0.95 & 6.2 & 0.49 & 65 \\
1.50 & 6.0 & 3.2 & 28 \\
1.50 & 6.2 & 1.2 & 41 \\
1.50 & 6.6 & 1.8 & 36 \\
2.63 & 5.9 & 2.1 & 31 \\
2.63 & 6.0 & 3.3 & 25 \\
\hline
\end{tabular}

filament did not exhibit the superconductivity at temperatures more than $4.2 \mathrm{~K}$. A straight line connecting the $T_{c}=7.2 \mathrm{~K}$ at $\mathrm{Pb}=100 \%$ and $T_{c}=3.4 \mathrm{~K}$ at $\mathrm{In}=100 \%$ is shown in Fig. 2 by a dotted line. The $T_{c}$ values of the $\mathrm{Pb}_{y} \operatorname{In}_{100-y}$ filaments $(y \geqq 25)$ lie at temperatures higher than those corresponding to the line. It was reported that the alloying of $\mathrm{Pb}$ with In within the solid solution limits led to a decrease in the $T_{c}$ to $6.6 \mathrm{~K}$ and the $T_{c}$ of the $\mathrm{InPb}$ phase (67 at $\%-86$ at $\%$ of $\mathrm{In}$ ) varied from $6 \mathrm{~K}$ to

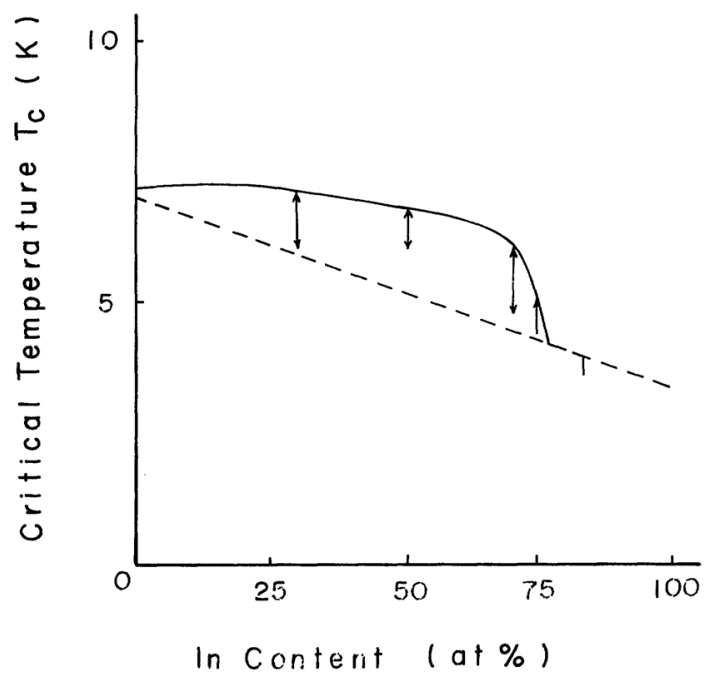

Fig. 2 The $T_{c}$ of the $\mathrm{Pb}$-In system alloy filament.

$4.9 \mathrm{~K}^{(10)}$. The $T_{c}$ of the present filament was in good agreement with these results.

The $T_{c}$ of the $\mathrm{Pb}-\mathrm{Sn}$ alloy filament is also measured. The $T_{c}$ of the filament did not de- 


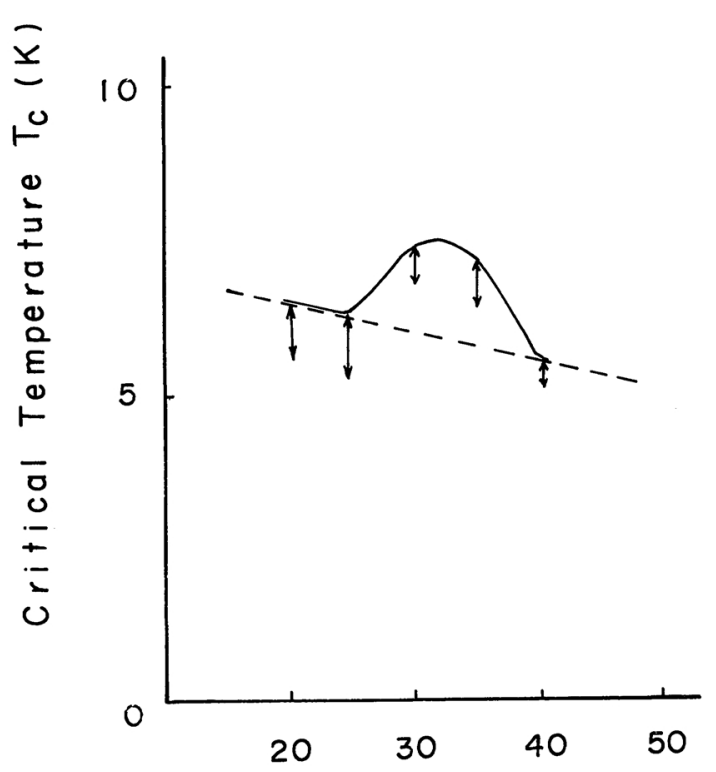

\section{Sn Content $(a+\%)$}

Fig. 3 The $T_{c}$ of the $\mathrm{Pb}-\mathrm{Sn}$ system alloy filament.

pend on the speed of spinning more on the $J_{s}$ less than $1 \times 10^{7} \mathrm{~A} / \mathrm{m}^{2}$ and is shown in Fig. 3 . The proportional allotment line of $T_{c}=7.2 \mathrm{~K}$ at $\mathrm{Pb}=100 \%$ and $T_{c}=3.7 \mathrm{~K}$ at $\mathrm{Sn}=100 \%$ is also shown in Fig. 3 by a dotted line. The maximum $T_{c}$ 's of the $\mathrm{Pb}_{80} \mathrm{Sn}_{20}, \mathrm{~Pb}_{75} \mathrm{Sn}_{25}$ and $\mathrm{Pb}_{60} \mathrm{Sn}_{40}$ filaments lie on this dotted line. It is noted that the $T_{c}$ 's of the $\mathrm{Pb}_{70} \mathrm{Sn}_{30}$ and $\mathrm{Pb}_{65} \mathrm{Sn}_{35}$ filaments are higher than those on the dotted line by about $2 \mathrm{~K}$. In the normal phase diagram of $\mathrm{Pb}-\mathrm{Sn}$ alloy, the maximum solubility in $\mathrm{Pb}$ is 29 at \% of $\mathrm{Sn}$ content at $456 \mathrm{~K}$, and the solubility of Sn remarkably decreased with decreasing temperature ${ }^{(4)}$. However, the extension of the solubility limit in the present filament formed by the rapid quenching was observed. The enhanced $T_{c}$ for the $\mathrm{Pb}-\mathrm{Sn}$ alloy filament may be associated with the structural instability ${ }^{(11)}$.

The $\mathrm{Pb}_{84.4} \mathrm{Au}_{15.6}$ and $\mathrm{In}_{2} \mathrm{Bi}$ filaments were produced by the same method as for the $\mathrm{Pb}$ filament. The average diameter, tensile strength and crystal structure of the filament spun at various spinning speeds are listed in Table 7. The $\mathrm{Pb}_{84.4} \mathrm{Au}_{15.6}$ filament spun at a spinning speed of $1.50 \mathrm{~m} / \mathrm{s}$ has a high tensile strength of $130 \mathrm{MPa}$ with the elongation of $2.5 \%$. The $\mathrm{Pb}_{84.4} \mathrm{Au}_{15.6}$ filament exhibited the superconductivity at $5.5 \mathrm{~K}$ and the $\mathrm{In}_{3}$ Bi filament at $5.6 \mathrm{~K}$. These results are in good agreement with that of the bulk alloys ${ }^{(12)}$.

In conclusion the continuous filaments less than $60 \mu \mathrm{m}$ in diameter of $\mathrm{Pb}$, and $\mathrm{Pb}-\mathrm{Bi}$, $\mathrm{Pb}-\mathrm{In}$ and $\mathrm{Pb}-\mathrm{Sn}$ system alloys could be produced by the glass-coated melt spinning. The $T_{c}$ of the $\mathrm{Pb}$ alloy filament did not depend on the $J_{s}$ less than $3 \times 10^{7} \mathrm{~A} / \mathrm{m}^{2}$, whereas the $T_{c}$ of the $\mathrm{Pb}$ filament depends on the $J_{s}$ more than $2 \times 10^{6} \mathrm{~A} / \mathrm{m}^{2}$. The maximum $T_{c}$ at $8.0 \mathrm{~K}$ was measured for the $\mathrm{Pb}_{60.2} \mathrm{Bi}_{39.8}$ filament. The enhancement of superconductivity was observed for the $\mathrm{Pb}_{70} \mathrm{Sn}_{30}$ and $\mathrm{Pb}_{65} \mathrm{Sn}_{35}$ filaments.

\section{Acknowledgements}

The author wishes to thank Prof. S. Yasukouchi, Nippon University, for his valuable suggestion. This work was partly supported by a Grant-Aid for Scientific Research from the Ministry of Education, Science and Culture (No. 57055028), Japan.

Table 7 Spinning conditions and average diameter, and crystal structure of the $\mathrm{Pb}_{84.4} \mathrm{Au}_{15.6}$ and $\mathrm{In}_{2} \mathrm{Bi}$ filaments produced by the melt spinning with pyrex glass.

\begin{tabular}{lccccc}
\hline \multicolumn{1}{c}{ Alloys } & $\begin{array}{c}\text { Winding speed } \\
(\mathrm{m} / \mathrm{s})\end{array}$ & $\begin{array}{c}\text { Diameter } \\
(\mu \mathrm{m})\end{array}$ & $\begin{array}{c}\text { Tensile strength } \\
(\mathrm{MPa})\end{array}$ & $\begin{array}{c}\text { Elongation } \\
(\%)\end{array}$ & Crystal structure \\
\hline $\mathrm{Pb}_{84.4} \mathrm{Au}_{15.6}$ & 0.95 & 58 & 70 & 1.7 & $\mathrm{~Pb}^{2} \mathrm{Au}^{*}$ \\
& 1.50 & 32 & 130 & 2.5 & \\
$\mathrm{In}_{2} \mathrm{Bi}$ & 2.63 & 43 & 80 & 1.3 & BiIn $_{2}^{* *}$ \\
& 0.95 & 89 & 20 & 6.3 & \\
& 1.50 & 37 & 20 & 3.1 & 7.3 \\
\hline \hline
\end{tabular}

Au*: $f c c$ with $a=4.08 \times 10^{-10} \mathrm{~m}$.

$\mathrm{BiIn}_{2}{ }^{* *}$ : hcp with $a=5.50 \times 10^{-10} \mathrm{~m}, c=6.58 \times 10^{-10} \mathrm{~m}$. 


\section{REFERENCES}

(1) T. Gotō: Trans. JIM, 22 (1981), 753.

(2) T. Gotō: Proc. 4th Int. Conf. on R.Q. Met., vol. 1. Japan. Inst. Metals., (1982), p. 1233.

(3) T. Totō: Trans. JIM, 23 (1983), 278.

(4) Japan Inst. Metals: Metal Data Book, Maruzen, Tokyo, (1974).

(5) J. G. Adler and S. C. Ng: Canad. J. Phys., 43 (1965), 594.

(6) J. H. P. Watson: J. Appl. Phys., 42 (1971), 46.
(7) J. Hasse and J. Seiberth: Zeit. Phys., 213 (1968), 79.

(8) G. Bergmann: Phys. Rep., 4 (1976), 159.

(9) T. Gotō: J. Soc. Fiber Science \& Technology, 34 (1978), T-237 (in Japanese).

(10) E. M. Savitskii, V. V. Baron, Yu. V. Efimov, and S. D. Gindina: Metalloved Tsuet. Metal. Spavov, 1972, 181, C.A., 79 (1973), 412.

(11) L. R. Testardi: Rev. Mod. Phys., 47 (1975), 637.

(12) V. D. I.: Lehrgangshandbuch kryotechnik (second Edition), Berline (1977). 